\title{
Bone marrow transplantation and adverse reactions present in post-transplantation patients: a literature review
}

\author{
João Batista Ramos Neto' ${ }^{1}$ Edilene Maria da Silva ${ }^{2}$;osefa Gisele Lima da Silva ${ }^{3}$; Keylla Arielle da \\ Silva Leite ${ }^{4}$; Georgia Lima de Freitas ${ }^{5}$; Ayanny Mayara de Oliveira Marinho6; Sidrielly Cecília \\ Clarice de Assunção ${ }^{7}$; Thalia Beatriz da Silva ${ }^{8}$; Esthefane Karine Brandão Santiago ${ }^{9}$; Noalyta Maelly \\ da Silva ${ }^{10}$; Evely Bezerra Melo de Araújo ${ }^{11}$; Janaina Barbosa da Silva ${ }^{12}$; Allyson Rodrigo de Oliveira \\ Lopes $* 13$
}

1 Undergraduate of the bachelor's degree in biomedicine at the Academic Center of Vitória de Santo Antão - UNIVISA
2 Undergraduate of the bachelor's degree in Nursing at the Academic Center of Vitória de Santo Antão - UNIVISA
3 Undergraduate of the bachelor's degree in Nursing at the Academic Center of Vitória de Santo Antão - UNIVISA
4 Undergraduate of the bachelor's degree in Pharmacy at the Academic Center of Vitória de Santo Antão - UNIVISA
5 Undergraduate of the bachelor's degree in Biomedicine at the Academic Center of Vitória de Santo Antão - UNIVISA
6 Undergraduate of the bachelor's degree in Nursing at the Academic Center of Vitória de Santo Antão - UNIVISA
7 Undergraduate of the bachelor's degree in Pharmacy at the Academic Center of Vitória de Santo Antão - UNIVISA
8 Undergraduate of the bachelor's degree in Pharmacy at the Academic Center of Vitória de Santo Antão - UNIVISA
9 Undergraduate of the bachelor's degree in Pharmacy at the Academic Center of Vitória de Santo Antão - UNIVISA
10 Undergraduate of the bachelor's degree in Pharmacy at the Academic Center of Vitória de Santo Antão - UNIVISA
11 Undergraduate of the bachelor's degree in nursing at the Academic Center of Vitória de Santo Antão - UNIVISA
12 Postgraduate degree in science education from the University Center of Vitória de Santo Antão - UNIVISA.
12 Professor of the Biomedicine course at the Academic Center of Vitória de Santo Antão - UNIVISA.

E-mail adresses: jb.neto@live.com. (João Batista Ramos Neto), edilene29.10@hotmail.com (Edilene Maria da Silva), giselelima1478@gmail.com (Josefa Gisele Lima da Silva), k.arielle@outlook.com (Keylla Arielle da Silva Leite) georgia_freitas@outlook.com (Georgia Lima de Freitas), ayannyoliveira@gmail.com (Ayanny Mayara de Oliveira Marinho) sidriellyassuncao@gmail.com (Sidrielly Cecília Clarice de Assunção), thaliafacul18@gmail.com (Thalia Beatriz da Silva), karineesantiago@hotmail.com (Esthefane Karine Brandão Santiago), noalytamaelly@gmail.com (Noalyta Maelly da Silva), evelyhipi@gmail.com (Evely Bezerra Melo de Araújo), prof.janainabarbosa27@gmail.com (Janaina Barbosa da Silva), Allysonlopes85@gmail.com (Allyson Rodrigo de Oliveira Lopes)

${ }^{*}$ Corresponding author

\section{To cite this article:}

Neto, J.B.R.; Silva, E.M.; Silva, J.G.L.; Leite. K.A.S.; Freitas, G.L.; Marinho, A.M.O.; Assunção, S.C.C.; Silva, T.B.; Santiago, E.K.B.; Silva, N.M.; Araújo, E.B.M.; Silva, J.B.; Lopes, A.R.O. Bone marrow transplantation and adverse reactions present in post-transplantation patients: a literature review. International Journal of Sciences. Vol. 2, No. 1, 2021, pp. 14-17. ISSN 2763-5392.

Received: 06 29, 2021; Accepted: 06 30, 2021; Published: 07 15, 2021

\begin{abstract}
The use of treatment through bone marrow transplantation has been very useful therapy and widely used in the fight against malignant and benign diseases. However, with appearances of some adverse reactions has unfavorable the development of such therapy. These types of reactions are related to the factor of histocompatibility between the donor and the recipient, with conditioning and type of graft that can be autologous or allogeneic. Developing complications after transplantation that may last for a long or short term. The aim of this research was to make an analysis of the reactions after autologous and allogeneic bone marrow transplantation. Utilizing the literature review method, obtaining the results for autologous and allogeneic transplantation, in which it was observed that adverse reactions may manifest between heart diseases, post-transplant procedure, complications of respiratory and pulmonary airways, liver complications and infections, in addition to the lack of care for patients.
\end{abstract}

Keywords: Disease. Adverse effects. Bone marrow transplant

\section{Introduction}

The bone marrow is the gelatinous tissue that is located within all the bones of our body, whose main function is to produce and maintain three cell lines. The cell lines that will make up peripheral blood are leukocytes, red blood cells and platelets (INCA, 2018). The bone marrow transplantation procedure can be performed in two ways, allogeneic when a 
compatible donor or autologous donor participates when the donation comes from the recipient itself. This procedure aims to replace the diseased or defective bone marrow with normal cells obtained through a donor or the blood of an umbilical cord, in order to reconstitute the bone marrow making it healthy (BRASIL, 2015).

There are some changes that are related to the adverse effects that some patients have at the end of the procedure, such as eye changes that have their risk of development in patients undergoing irradiation. Cardiopathy is the development of heart diseases due to the use of radiotherapy and cardiotoxic chemotherapy and possible infections that can be viral, fungal and bacterial (SILVA; SOUZA, 2020).

Rejection can be triggered by antigens with lower histocompatibility that plays an important role in the immune system where it will triggermen data responses when exogenous agents are identified to the organism (SILVA; SOUZA, 2020).

The histocompatibility process encodes a group of proteins or antigens identified on the cell surface human leukocyte antigen or by killer immunoglobulin receptors. Thus, compatibility tests are performed between the recipient and the donor, with the objective of reducing the risks of complications after the occurrence of bone marrow transplantation (SILVA; SOUZA, 2020).

When other alternative methods are unsuccessful, BONE MARROW TRANSPLANTATION (MOT) will continue as the only possible treatment to treat different pathologies. Histocompatibility between donor and recipient is one of the key factors for transplant success. Many patients have not found an ideal donor in the family, they may choose to find an HLA-compatible donor through REDOME (National Registry of Bone Marrow Donors) (REDOME, 2018).

However, after performing the transplant, immunity weakens due to the stages that patients are submitted, in the period of pancytopenia, when all blood cells decrease red blood cells, platelets and leukocytes, the patient becomes quite fragile subject to possible infections, organ involvement, in addition to psychological problems. For transplantation to occur it is necessary to destroy the bone marrow, with the following reconstitution of the same that can last for years or months, it will depend on the cell line (MARQUES et al., 2017).

With the occurrence of bone marrow destruction and subsequent recovery, it occurs that the graft recipient can absorb some changes complicating its development in the post-transplant period, making it difficult to quality of life. This is due to the processes to which the patient is submitted to be able to perform the transplant. Even though the therapeutic process aims to cure the patient, still, the onset of diseases or even death can occur (PROENÇA et al., 2016).

It is noted that after performing the bone marrow transplant, the patient is vulnerable to present different pathologies (SILVA; SOUZA, 2020). The study aims to understand the possible reactions that the patient may present. Published articles were used that demonstrate the possible occurrences of adverse effects that hinder the patient's quality of life after transplantation, since complications have great influence on patients' lives.

\section{Methodology}

For the construction of this work, articles already published in the databases were researched: Virtual Health Library, Pubmed, Scielo, Revista Brasileira de Enfermagem. The study used as a basis articles addressing bone marrowtransplantation. Using the following descriptors: Bone Marrow Transplantation, diagnosis, adverse reactions, posttransplant treatment, post-transplant patientcare. We select publications in English and Portuguese published in the period 2015 to 2020 .

The study method was based on articles that addressed only the criterion within the research lineage, which was based on insertion criteria that dealt with bone marrow, umbilical cord or peripheral blood transplantation. The selected studies served as a reference.

\section{Results and Discussion}

Table 1 shows the number of transplants performed in each state between 2012 and 2019. However, the difficulties of finding a compatible donor have impaired the progress of this therapy, the incentive to give and perform voluntary registrations have grown considerably, improving the possibilities of finding a compatible donor not related and thus increasing the number of transplants that are realized (PACHECO; PEREIRA, PAIVA, 2017).

\begin{tabular}{c|c|c|c}
\hline \multicolumn{5}{c}{ Table 1. Transplant numbers in the 12 states } \\
\hline States & Allogeneic & Autologous & total \\
\hline SP & 789 & 976 & 1,765 \\
\hline MG & 93 & 237 & 330 \\
\hline RJ & 100 & 214 & 314 \\
\hline PR & 159 & 151 & 310 \\
\hline PE & 76 & 156 & 323 \\
\hline RS & 58 & 154 & 212 \\
\hline EC & 29 & 98 & 127 \\
\hline SC & 21 & 98 & 119 \\
\hline DF & 28 & 89 & 117 \\
\hline BA & 34 & 77 & 111 \\
\hline RN & 27 & 69 & 96 \\
\hline GO & 14 & 58 & 72 \\
\hline Brazil & 1,428 & 2,377 & 3,805 \\
\hline Se: Brazin
\end{tabular}

Source: Brazilian Transplant Registry, 2019.

According to the data obtained autologous transplantation has a big difference about allogeneic transplantation, the state of São Paulo led with 976 cases of autologous transplantation, followed by Minas Gerais with 237. Totaling 3,805 autologous and allogeneic transplants performed during this period.

Adverse reactions after transplantation can bring serious 
problems to the patients, the study conducted by SILVA; SOUZA (2020) it was reported that the complications after the procedure have developed difficulties for the recovery of transplanted patients, such as cardiac complications that have their development due to exposure to cardiotoxic chemotherapy and radiotherapy.

Cardiac complications have more apparition in autologous transplantation while in allogeneic transplants, are cardiomyopathies, congestive heart failure, valvular dysfunction, pericarditis, coronary artery disease and arrhythmia. Having women with risks of appearance three times greater (SILVA; SOUZA, 2020).

In BARRETTA et al. (2016), a study was conducted on complications of central venous catheter in patients transplanted with hematopoietic stem cells in a specialized service, where there were 188 patients, 110 of them male. The catheter that was most used was the Hickman model, which has a large increase in use in cancer patients and in patients who need bone marrow transplantation, secondly, the Double Lumen.

Complications by central venous catheter were more associated with autologous transplantation, although the conditioning used does not cause immune-ablation, such as in allogeneic transplants that, in union, produce hematopoietic pancytopenia and immunocytopenia, conducive to the occurrence of opportunistic infections. Infections and obstruction are the most common occurrences and may be immediate or late, developed by several factors, such as surgical technique used, insertion site, type of cancer and incorrect handling (BARRETTA et al., 2016).

For the use of the central venous catheter, some factors are taken without consideration, such as the type of conditioning, the purpose, the patient's age, the duration of treatment, training of the professional who will handle, because the infections correlated to the central venous catheter can be avoided (BARRETTA et al., 2016).

According to MARQUES et al. (2018) in a study conducted in Brazil in the city of Campinas, São Paulo, with 62 patients who underwent autologous and allogeneic bone marrow transplantation. Regardless of clinical differences, patients presented similar changes in quality of life domains. Although there is a high mortality rate $(21 \%)$, a significant portion of patients can survive therapy. It is important to know the profile of these patients and the changes that will affect their quality of life.

In a study conducted by MARQUES et al. (2017), patients presented symptoms of fatigue, insomnia and loss of appetite, interfering in physical, emotional and social functions, correlating the side effects of treatment causing an impact on the quality of life of patients. The loss of appetite had greater intensity in autologous transplants in the pretransplant period, allogeneic patients presented in the post100-day stage. The clinical alteration in autologous and allogeneic patients were similar in quality of life, however, there is a lack of materials that objective to analyze the differences in quality of life among patients undergoing this therapy (MARQUES et al., 2017).

It is noted that despite being a rigorous and aggressive therapy that can lead to various complications, patients who survive consider their quality of life good, gradually resuming their routine. It is important that responsible health teams are close to patients, clarifying doubts and guiding, therefore, it has to be attentive to the possible appearances of signs and related symptoms.

\section{Conclusions}

Bone marrow transplantation is used for various pathologies, but the adverse reactions that are presented have impacted the quality of life of patients. It may have a variable of diseases, or even have a similarity. In this study it was possible to analyze some factors of appearance in transplanted patients, noting that most adverse reactions are related to infections and graft-versus-host disease.

Complications such as heart diseases, a post-transplant procedure in which we can mention the central venous catheter, airway and pulmonary complications, liver complications and infections, is present in most patients, observing this wide number of complications among various transplant sectors. It is important to have more studies focused on this therapy, as well as research to confirm the adverse effects and their prophylaxis, aiming to make bone marrow transplantation a more effective therapy.

\section{Acknowledgements}

I thank God for giving me the strength and courage to never give up, to all my family, for the support, especially my mother, I thank the friends who were present during the five years of the course, to my advisor Allyson Lopes for the support and encouragement to always improve.

\section{References}

[1] AACC. Associação de apoio à criança com câncer. Transplante de medula Óssea. 2017. Disponível em $<$ www.aacc.org.br/transplante-de-medula-ossea $>18$ mar. 2021

[2] BARRETTA, L.M. et al. Complicações de cateter venoso central em pacientes transplantados com células-tronco hematopoiéticas em um serviço especializado. Rev. Latino-Am. Enfermagem. Ribeirão Preto. 2016; Disponível em: http://dx.doi.org/10.1590/1518-8345.0547.2698. Acesso em: abril de 2021.

[3] MARQUES, A.B.C. et al. Hematopoietic stem cell transplantation and quality of life during the first year of treatment. Ver. Latino-Am. Enfermagem. 2018; Disponível em: HTTP://dox.doi.org/10.1590/1518-8345.2474.3065. Acesso em: abril de 2021.

[4] MARQUES, A.C.B. et al. Qualidade de vida nos primeiros seis meses pós-transplante de células-tronco hematopoéticas. Enferm. Curitiba, Paraná, Brasil 2017; Disponível em: https://www.scielo.br/scielo.php?script=sci_arttext\&pid=S010 4-07072017000300331\&lng=pt\&tlng=pt. Acesso em: abril de 2021.

[5] Ministério da Saúde (BR), Biblioteca Virtual em Saúde (BVS). : Transplante de medula óssea. Disponível em: http://bvsms.saude.gov.br/dicas-em-saude/2127-transplante- 
4 Neto, J.B.R.; Silva, E.M.; Silva, J.G.L.; Leite. K.A.S.; Freitas, G.L.; Marinho, A.M.O.; Assunção, S.C.C.; Silva, T.B.; Santiago, E.K.B.; Silva, N.M.; Araújo, E.B.M.; Silva, J.B.; Lopes, A.R.O. Bone marrow transplantation and adverse reactions present in post-transplantation...

de-medula-ossea. Acesso em: abril de 2021.

[6] Ministério da saúde (BR), Instituto Nacional (INCA). Transplante de Medula Óssea. Disponível em: https://www.inca.gov.br/tratamento/transplante-de-medulaossea. Acesso em: abril de 2021.

[7] PACHECO, D.F.; PEREIRA, L.F.F.; PAIVA, J.L.; Transplante de medula óssea em pacientes com anemia falciforme. FEF. 2017; Disponível em: www.fef.br. Acesso em: abril de 2021.

[8] PENNA, G.B. Capacidade funcional, função pulmonar e qualidade de vida de sobreviventes do transplante de célulastronco hematopoéticas. Universidade federal do rio grande do Sul, Porto Alegre, Brasil 2020; Disponível em: https://www.lume.ufrgs.br/bitstream/handle/10183/211296/00 1115078.pdf? sequence $=1 \&$ isAllowed $=$ y. Acesso em: abril de 2021.

[9] PROENÇA, S.F.F.S. et al. Quality of life of patients with graftversus-host disease (GvHD) post-hematopoietic stem cell transplantation. Rev Esc Enferm USP. 2016;50(16):951-958. Disponível em: http://dx.doi.org/10.1590/S0080623420160000700011. Acesso em: abril de 2021.

[10] REDE BRASILEIRA DE TRANSPLANTE (RBT). Ano XXV $\mathrm{n}^{\circ}$ 4. Dimensionamento do transplante no Brasil e em cada estado (2012-2019). Disponível em: www.abto.org.br. Acesso em: abril de 2021.

[11] SILVA, M.J.S; SOUZA, P.G.V.D. Desenvolvimento de doenças e complicações após transplante de medula óssea. Braz. J. of Develop., Curitiba, Paraná, 2020. Disponível em: www.brazilianjournals.com/index.php/BRJD/article/view/216 22/17245. Acesso em: abril de 2021.

[12] SOUZA, P.F.A.; Doença do enxerto versus hospedeiro: fisiopatologia e implicações clinicas. Brasília, Brasil, 2019; Disponivel em: https://repositorio.uniceub.br. Acesso em: abril de 2021.

[13] TUZOVIC, M. et al. Cardiac Complications in the Adult Bone Marrow Transplant Patient. 2019; Disponível em: www.escholarship.org/uc/item/9vc520gp. Acesso em: abril de 2021. 